\title{
Language Use and Context in the Campaign Songs of the Chuka Community in Kenya
}

\author{
Onesmus G. Ntiba \\ School of Education, Mount Kenya University \\ ontiba@yahoo.com
}

\section{Doi:10.5901/mjss.2014.v5n5p}

\section{Abstract}

In this study, I propose to analyze language use and context as depicted in the campaign songs of the Chuka Community in Kenya. Chuka community is one of the seven subgroups of the larger Meru Ethnic Community found in Kenya. The other subgroups of the Ameru are the Mwimbi, Tharaka, Imenti, Tigania, Igoji and the Igembe people. The Chuka people speak the Kichuka dialect. When the tradition of choosing political leaders through the ballot set in Kenya during the colonial period, many ethnic communities in Kenya started using campaign songs as a way of drumming support for the favoured political candidate. The Chuka people were not left behind. To date, these campaign songs have played and have continued to playing a vital role during every electioneering period. The politicians and their supporters compose these political songs with a view of appealing to the electorate emotions if not their reasoning. In analyzing these campaign songs, I have been informed by some tenets of the Critical Discourse Analysis theory thereafter referred to as C.D.A. Basically, this theory looks at language as used in a certain context for sole purpose of passing a certain message. The linguistic units in a discourse play a pivotal role in passing of this intended message. On guidance of this principle, I was able to closely examine how certain words; proper nouns, verbs and adjectives have been used purposefully in these Kichuka campaign songs to sway the mind of the electorate for a political gain. The analyst is of the view that the composers of these campaign songs are products of the place, time and Chuka cultural environment. Indeed, the analyst is treating the Kichuka Campaign songs as discourses in a known and specific context. This is in line with another tenet of the CDA theory that boasts of the fact that exhaustive interpretation of a discourse should factor the issue of context. This analysis subscribes to the fact that purposive usage of linguistic units like words or group of words in a certain political context gives the politicians a leeway to wrest political power from the electorate for their own selfish ends. This analysis submits that the campaign songs in the Chuka Community have to a reasonable degree influenced the course of the political events in the community and subsequently the low achievement in terms of development in the area.

Keywords: Language, Songs, Message, Literature, Community

\section{Introduction}

This article is based on the first objective of a research I carried out in July to September 2013 in the three divisions of Magumoni, Chuka and Igambang'ombe found in Tharaka Nithi County, Kenya. I collected a data of fourty Kichuka campaign songs sung during the general elections conducted in 1992, 1997, 2002, 2007 and 2013 in Kenya. The composers of these campaign songs sung praises for the candidacy they endorsed while simultaneously ridiculing political hopefuls whom they disliked.

According to Guthrie (1967), the Chuka people is one of the seven sub-groups of the Meru of Kenya who it is believed originated from the Island of Mboa found in East African coast. They migrated from this Island due to afflictions they suffered from their tormentors whom they referred to as 'Nguo Ntune' (Red clothes). It is possible that these were Arabs who had settled there for purposes of trade. Mwaniki (2004) says that the oral traditions has it that the Chuka and Tharaka subgroups of the Ameru are sons and daughters of one person called Muchuka. This attests to the large similarity evident in the language and cultural beliefs of these people when compared with the other subgroups of the Meru Community. Were and Wilson 1972 describes the Achuka as one of the Bantu speaking people found on the slopes of Mount Kenya. Making reference to political songs, Mwaniki (1986) lays claim that the origin of the campaign songs in Kenya can be traced back to 1957 when the British Colonialist allowed the locals to elect their representatives to the Legislative Council (Legco). Since then, every election campaign is translated to a period of power contestation. Those Africans who were interested in these political posts had to campaign to win more supporters. Language as was used in these Kichuka Campaign songs was geared towards convincing the electorate that a certain politician was the best. These Kichuka campaign songs continued to grow and metaphorse to accommodate the changing times in terms of language use, style and content. This is characteristic of African way of life that every activity and ceremony is not complete if it's not spiced with songs and dances that befit the occasion. 
Language in the Kichuka campaign songs is so appealing. However, you will witness minor differences in style depending on the composer of the songs. This is in agreement among literary critics that the style is the person. Luke (2005) lays claim that the recipients of political songs at times act on the basis of the messages in these songs without giving much a thought. Analyzing language use in a discourse, Mathooko (2007) says that the 'user' of the linguistic units may use them depending mostly on his stand points, interests and attitudes regarding various issues in their communities.

Mesthrie et al (2000) points out that analysis of language use in a discourse must put into consideration its rightful context. A close examination of a discourse will elicit indicators which define the context to which the discourse in question can be attributed to. In this regard, selected tenets of the C.D.A theory have helped the analyst to analyse language use in selected Kichuka campaign songs. In this work, I shall first embark on language use analysis and thereafter the context as depicted in these Kichuka campaign songs.

\section{Language Use}

In this section of my discussion I shall focus on the linguistic units the composers of Kichuka Campaign songs were employing to pass their message to the electorate. On analyzing the data, I identified three linguistic units widely used the sounds, words and phrases. Certain vowel sounds were used to contribute to the creation of the coherence in these songs. The Kichuka dialect has a total of seven vowels: $a, \varepsilon, i, \supset, u, e, 0$. Out of these, four were used for this purpose. These are [a], [e], [i], and [o]. On top of playing a contributory role in creating coherence in these songs, they played a very vital role in giving these songs a poetic note by ensuring that there was some rhythm in these songs. For example;

\begin{tabular}{|c|c|}
\hline $\begin{array}{l}\text { Stanza } \\
\text { liii Ruguti } \\
\text { liii Ruguti } \\
\text { ii Rwicuraga } \\
\underline{\text { i Kirauko Ruguti }}\end{array}$ & $\begin{array}{l}\text { Translation } \\
\text { liii Ruguti } \\
\underline{\text { liii Ruguti }} \\
\text { ii it swells } \\
\underline{\text { in in the morning }}\end{array}$ \\
\hline
\end{tabular}

The Kichuka dialect has a heavy bias of consonant vowel (CVCV) arrangement of the syllables in its words. This characteristic of the Kichuka words helped the composers to inflect (Chukanise) some of the English words to fit into the Kichuka word order. For example;

English word
County
Governor
Senator
County representative
Mister
Parliament

Examine these words in the context of usage;

\section{English word}

County

Parliament

\section{as used in Kichuka} Campaign Songs

Ithii mbere Kaunti yetu: Ithii mbere Ithii mbere Kaunti yetu: Ithii mbere

Na Kindiki araugire:

Ithii mbere

Nibu tukuga Tharaka Nithi

\section{Muthomi akuthii:}

Baliamenti ii

Wenda gwicuria:

Ruma mukanda ii

\section{Translation}

Be developed our County:

Be developed

Be developed our County:

Be developed

And Kindiki has also said:

It be developed

That's the assertion of Tharaka Nithi

Muthomi has gone:

To parliament

If you are irked:

you can go hang 


\begin{tabular}{|c|c|c|}
\hline Governor & $\begin{array}{l}\text { Giti kia ngabana: } \\
\text { Kaunti ino yetu } \\
\text { Ni kia mukuru Ragwa: } \\
\text { Niwe ugakibota }\end{array}$ & $\begin{array}{l}\text { The governor's seat: } \\
\text { In our County } \\
\text { Belongs to Ragwa: } \\
\mathrm{He} \text { is able }\end{array}$ \\
\hline County & I kaunti rebu: & Our County representative \\
\hline Representative & Ni mista Roy & Is mister Roy \\
\hline Mister & Niwe uyu & Here he is \\
\hline & Niwe uyu & Here he is \\
\hline & Niwe uyu & Here he is \\
\hline Senator & $\begin{array}{l}\text { Ndegwire makiurania, } \\
\text { Sinita wetu ni uriku } \\
\text { Ni Kindiki, ni Kindiki } \\
\text { Uria ukuga tiwe niwe }\end{array}$ & $\begin{array}{l}\text { I have heard them wonder } \\
\text { who is our senator } \\
\text { It's Kindiki, It's Kindiki } \\
\text { let everyone know this }\end{array}$ \\
\hline
\end{tabular}

In these Kichuka campaign songs, the composers at times create new words from the already existing ones. For example an adjective 'murembeko' (ugly) is created from the adjective 'murembo' (beautiful). It is interesting to note the word 'murembeko' was created during the 2013 general elections among the Chuka people. The candidate the composers were endorsing was regarded as 'beautiful' whereas his opponents were referred to as 'ugly'. In this context, the 'beautiful' is good and for that reason should be elected as the M.P whereas the ugly should not be elected. Look at this:

\begin{tabular}{ll} 
Stanza & Translation \\
Muthomi ni: & Muthomi is: \\
Murembo & Beautiful \\
\hline Mau mangi ni: & others are: \\
Murembeko & $\underline{\text { ugly }}$
\end{tabular}

According to linguists, there are eight categories of words. However, after analysing the data I had collected, I noticed that in these Kichuka campaign songs, the proper nouns, verbs and adjectives were used by the composers in a special way to achieve a particular political aim. Name nouns were used to make reference to certain politicians who could correctly be placed in a certain historical epoch of the Chuka people. Examine this:

$\begin{array}{lc}\text { Name of a politician in the song } & \text { Election period } \\ \text { Njoka } & 1992 \\ \text { Njoka and Kapteni } & 1997 \\ \text { Kapteni, Petkay Miriti, Mati, Njeru and Karagita } & 2002 \\ \text { Petkay Miriti, Kaburu, Kareke and Nthuraku Gichuiya } & 2007 \\ \text { Muthomi Njuki, Mbaabu, Beatrice Nkatha, Kindiki, Ragwa and Roy } & 2013\end{array}$

NB

The names here appear as they are in the campaign songs. That is why some politicians in the songs were made reference to by one name instead of two or three as its characteristic of people's names.

The composers used these names to bring the politicians into limelight for electorate scrutiny and assessment. It was a way of identifying them for all and sundry. After identifying them, the composers did the next thing of either highlighting their strengths with the sole aim of endorsing their candidature or bringing to the open their weaknesses with the aim of comparing them unfavourably with their preffered candidates. This way, they 'destroyed' politically the candidate they disliked. Place nouns of two types were identified in these Kichuka campaign songs. There were those that made reference to places in Tharaka Nithi County in Kenya and those making reference to places outside even Kenya. Example of place nouns in the county:

$\begin{array}{ll}\text { Stanza } & \text { Translation } \\ \text { Nauma Chuka: } & \text { I am from } \underline{\text { Chuka: }} \\ \text { Kuria ukuru } & \text { To seek counsel }\end{array}$




$\begin{array}{ll}\text { Stanza } & \text { Translation } \\ \text { Wathii Muthambi } & \text { If you go to Muthambi: } \\ \text { Kura ni Ciake } & \text { Votes are his } \\ \text { Wathii Mwimbi: } & \text { If you go to Mwimbi: } \\ \text { Kura ni Ciake } & \text { Votes are his }\end{array}$

Examples of place nouns outside Kenya:

\section{Stanza}

Karagita ni muti,

Mubande ruuini,

Rwa Jerusalem,

Atinkienyenyeka

\section{Stanza}

Ni sinita wa nguvu, Na ni wakili munene

Agendaga nkinya $\underline{\text { Hague }}$

Kumateterera Akenya

Ni Kindiki, Ni kindiki

Uria ukuga tiwe niwe

\author{
Translation \\ Karagita is a tree, \\ Planted in the waters, \\ Of Jerusalem, \\ $\mathrm{He}$ is unshakable

\section{Translation} \\ He's a power senator, \\ And a tough lawyer, \\ Who goes even at the Hague, \\ To represent Kenyans \\ It's Kindiki, It's Kindiki \\ Let it be known to all
}

The stanza in the first song above talks of a politician by the name Karagita who is as strong as a tree that is planted in the waters of Jerusalem. Mention of Jerusalem is symbolic in that most of the Chukanese are Christians who strongly believe that Jerusalem is the city source of peace, power and salvation for Christians worldwide. In the second song, reference is made to a lawyer cum politician who was seeking to be elected as the first senator in Tharaka Nithi County. To the composer, Kindiki qualifies for this position because he is a reknown lawyer of International standards who even represents some Kenyans in the International Criminal Court (I.C.C.) at the Hague in Netherlands. To associate these two politicians with Jerusalem and Hague is meant in one way or the other to demonstrate to the electorate that they qualify for the political seats they are seeking. It's a way of endorsing their candidature.

The other categories of words noted by the analyst for their specialty are the verbs. According to Mgullu (1999), verbs are the 'doer' words. They are action words. Kichuka is an agglutinating language and for this reason the Kichuka verb has morphemes that indicate time of the action in various ways. There are various examples in these Kichuka campaign songs:

\section{- Past acts eg}

Ithii mbere Kaunti yetu:

Ithii mbere

Ithii mbere Kaunti yetu:

Ithii mbere

Na Kindiki araugire:

Ithii mbere

Nibu tukuga Tharaka Nithi

- Actions to be done now e.g

Kanyiri kainagua ni mwene:

Nitumuthureni

Uyu ni kana getu:

Nitumuthureni

Au nibo turi:

Nitumuthureni

Kanyiri kainagua ni mwene

- Acts to be done in future e.g

\section{Stanza}

Muntu utigakira,

Arume kuu mbunge,

Ni meya uyu Mbaabu

\section{Translation}

Development is our County:

Development

Development is our County:

Development

Even Kindiki has asserted:

Development

That's the verdict of Tharaka Nithi

\section{Translation}

A people loves their Kinsman:

Let's elect him

This is our child:

Lets elect him

That's our decision:

Lets elect him

A people loves their Kinsman

\section{Translation}

He who will not fear,

Other men in parliament,

Is Mayor Mbaabu 


\section{Stanza}

Giti kia ngabana:

Kaunti ino yetu

Ni kia Mukuru Ragwa:

Niwe ugakibota

- Continous acts eg

\section{Stanza}

Nthaka, nthaka, nthaka

Nthaka ni Kithaka nthaka

Igendaga mbere ya riua

\section{Stanza}

Kaburu ii:

Ruga nyungu ndume

Nuntu mau mangi:

Marugaga na rugio

\section{Translation}

The seat of the governor:

In our County

Belongs to Honourable Ragwa:

He will be able

\author{
Translation \\ Young men, young men, young men, \\ Young men are like bushes \\ Young men wakes up before the sun rises
}

\section{Translation \\ Kaburu ii: \\ Cook the pot we eat \\ Because these others: \\ Cooks using broken pots}

Munene (2011) submits that the Kichuka verb root is capable of accommodating both prefixes and suffixes. The various verbs in Kichuka campaign songs:

- Makes reference to past acts and events

- Calls for what to be done now.

- Calls for action in the future.

- Enlightens on what should always be done.

All these actions is one way or the other play a crucial role is highlighting what a certain candidate has done, is doing, will do and then proceeds in calling the electrorate to take a bold step of either electing him or her or denying him or her the votes outrightly.

The last category of words I paid special attention to are the adjectives. Habwe and Karanja (2004) asserts that adjectives play the role of describing a noun. In this study, I focused mainly on the adjectives that:

- $\quad$ Show possessiveness (vivumishi vimilikishi)

- Describes one's character (vivumishi vya sifa)

- Show reference to places, politicians and their actions.

The focus on these three is based on the fact that the research I carried out has shown that these adjectives tells us more about various politicians, their actions and the places they come from. Let's examine them one by one:

\subsection{Adjectives that show possessiveness.}

The composers of these Kichuka Campaign Songs show possession of one kind or the other. For example they demonstrate that the politician they endorse is 'theirs' and come from their place. The area they want him or her to represent is their place. They are to make a political decision using their votes. Look at this:

$$
\begin{aligned}
& \text { Lines from various songs } \\
& -\quad \frac{\text { Uyu ni kana getu }}{\text { Ithii mbere Kaunti yetu }} \\
& -\quad \frac{\text { Wakwa muti }}{\text { Muti uyu waku iii: }} \\
& -\quad \text { Utikauringie }
\end{aligned}
$$

\author{
Translation \\ This is our child \\ Development in our County \\ My vote \\ Your vote \\ Use it on our child
}

\subsection{Adjectives that show one's character}

The composers use these adjectives to either 'build' the politician they prefer or to taint negatively the opponent they desire to bring down politically. Look at this: 


$\begin{array}{ll}\text { 1. Stanza } & \text { Translation } \\ \text { Ndungamirira: } & \text { Guard me: } \\ \text { Nkinye mucii uyu } & \text { As I enter this compound } \\ \text { Giria ukinyua mbere: } & \text { Before: } \\ \text { Ni ntuuri ii } & \text { This fool does so }\end{array}$

In this particular song, the contestant whose candidature is not preferred by the composers of this song is referred to as 'ntuuri' meaning 'a fool'. By referring to him as a fool, they are implying that he ought not to be voted in the political seat he is seeking.

\section{Stanza}

Ni sinita wa nguvu

Na ni wakili munene

Agendaga nkinya Hague

Kumatetera Akenya

Ni Kindiki, ni Kindiki

Uria ukuga tiwe niwe

\section{Translation}

He's a powerful senator

And a tough lawyer

Who goes even to the Hague

To represent Kenyans

Its Kindiki, It's Kindiki

Let it be known to all

Here, the aspirant for senatorial seat in Tharaka Nithi County is praised as:
'Sinita wa nguvu'
A powerful senator
'Wakili munene'
A tough lawyer

Because of his unequalled toughness and power, he ought to be elected as a senator of Tharaka Nithi County.

\section{Stanza \\ Uri nchamba: \\ Tharathara maguru \\ Tukubire: \\ Na mbunge ii}

\author{
Translation \\ You are tough: \\ Hurry up \\ We take you: \\ To parliament
}

In the stanza of this particular song, Nthuraku Gichuiya is referred as 'nchamba' meaning 'tough'. According to the traditions of the Chuka people, 'male' (nchamba) is associated with ability and power. In this sense, the politician is described as one who has the power and ability to deliver development if he is elected to a political office he is seeking.

\subsection{Adjectives making reference to politicians, their locations and votes to be used e.g}

\section{Stanza \\ Ndungamirira: \\ Nkinye mucii uyu \\ Giria ukinywa mbere: \\ Ni ntuuri ii}

\section{Stanza}

Kura ni ciake ii

Ni mista Roy

Niwe uyu

Niwe uyu

Niwe uyu

\section{Stanza}

Muti uyu waku ii

Utikauringe

Wakorwa nukwenda

lii maendeleo

\section{Translation}

Guard me:

As I enter this compound

Before:

This fool does so

\section{Translation}

We will vote him in

This Mr. Roy

This one

This one

This one

Translation

This vote of yours

Don't misuse it

If you really deserve

Development

In the three stanzas above (from different campaign songs) the composers use these adjectives to show who should be elected, who should not be elected, the place where the elected work and the item (vote) to be used to propel 
the preffered candidate to parliament hereby in the song reffered to as 'mucii uyu' meaning 'this compound'.

This study submits that there is open defiance of grammatical correctiveness of the usual Kichuka sentences. This is characteristic of songs because they are kind of poems. This defiance among other things gives these Kichuka Campaign songs a poetic note. However, since these songs are discourses, there is evident coherence which has been created by conjuction, reference words, message and characterization. These coherence units contribute greatly in making concerned songs as identifiable discourses with a particular message targeting a particular group and in the context of our study; the Chuka electorate.

\section{Context}

Every discourse should be contextualized. Msanjila (1989) and Mathooko (2007) admit that the issue of context is critical in sociolinguistics. Serious consideration of the context is necessary when a critical analyst purposes to attempt to bring the message in a certain discourse into the open. This applies to Kichuka campaign songs which the analyst has subjected to this kind of scholarly scrutiny. Msokile (1993) echoes literary critics like Hirsch (1967) and Birch (1989) by saying that a composer or a writer is a product of a certain time, place and cultural environment. A literary critic cannot and should not try to ignore contextual influences in production of a discourse in question. Any attempt to do this translates to unconscious attempt not to fully grasp the message in the concerned discourse. The analyst in this context takes this as truth and goes ahead to pay attention to the context of the Kichuka campaign songs.

The campaign songs used in this study can be placed into a specific place, time and cultural frameworks. The message evident in these songs is highly influenced by the Chuka society. The composers of these songs are the Chuka people and in these songs they portray their deep understanding of the cultural and political situation in their environment. In our systematic analysis of these contexts, I shall first focus on place context.

\subsection{Place Context}

In these campaign songs, there is direct mention of the geographical areas these politicians hail from, common areas like parliament or town council and reference to certain places symbolically.

\subsubsection{Specific geographical areas e.g.}

\section{Stanza \\ Nauma Chuka: \\ Kuria ukuru \\ Nerwa ni Mati: \\ Uri gitini ii}

\author{
Translation \\ I am from Chuka: \\ To seek counsel \\ I have been informed: \\ Mati has worn the seat
}

Chuka town is central to the people of Chuka community. It is the sub-county headquarter and several government and business premises are located here. After elections are conducted, the counting of the votes is done here. So, it can be correctly concluded that Chuka is the heartbeat of the Chuka people in Kenya. In the stanza of this particular song, the composers are laying claim that on seeking information from the sub-county headquarters, they have been reliably informed that a politician by the name Mati has won the seat of the counselor. There is a widespread belief that 'to win votes in Chuka, you must get the support of the inhabitants of Chuka town and its environs'.

\section{Stanza}

Antu ma Chuka Igambang'ombe,

Kura ni kwa Muthomi,

Tutikwenda mangi,

Kura cietu ni ciake.

\author{
Translation \\ People from Chuka Igambang'ombe, \\ Let's cast our votes to Muthomi, \\ Leave others alone, \\ Let's give him all our votes.
}

The Chuka Igambang'ombe constituency mentioned here is a new area curved in 2013 from the earlier one of Nithi. In this particular song, the electorate in Chuka Igambang'ombe are being implored to cast all their votes to Mr. Muthomi for the seat of the M.P. The Nithi Constituency had been curved by the Kenya Electoral and Boundaries Commission in 2013 into two namely Chuka Igambang'ombe and Maara. The campaign song below mentions Nithi constituency before it was curved into these two areas. 


\section{Stanza}

Niwe Nithi ikuthura,

Kinyu ii

lii kinyu

Kinyu ii

lii kinyu

Muntu uria

Ukinyite Petkay amukinyuke

\section{Translation}

Nithi people will vote him in,

Don't step on him

Please don't

Don't step on him

Please don't

He who

Is stepping on Petkay should stop

In this particular campaign song, the composers are asking Petkay's opponents to clear way for him so that he can easily go to parliament to represent their interests.

\title{
3.1.2 Common places e.g
}

\section{Stanza \\ Muthomi akuthii: \\ Baliamenti ii \\ Wenda gwicuria: \\ Ruma mukanda ii}

\section{Stanza}

Niwe tukuthura:

Atinkienyenya

Kuthii kuu gwa kanju:

Atinkienyenya

Tukenete muno:

Atinkienyenya

\author{
Translation \\ Muthomi has gone: \\ To parliament \\ If you are irked: \\ You can go hang

Translation
We will vote him in:
He should not worry
To the Town Council:
He should not worry
We are very happy:
He should not worry

These stanzas are from two different Kichuka campaign songs. In these two songs, mention is made of the two places where those elected converge to discuss affairs affecting those who elected them. The parliamentarians meet in the parliament (National Assembly) whereas councilors meet in the town council. In the stanza of the first song, the people are rejoicing that their candidate by the name Muthomi has won the seat of the M.P. In the second song, the composers are loudly stating the decision they have made to vote for a certain politician to the seat of the counselor. They are encouraging him to soldier on because they are fully behide him.

\subsubsection{References to places symbolically}

In this study, I have given two examples of how place context is made reference to symbolically in the Kichuka campaign songs e.g

\section{Stanza \\ Ndungamirira: \\ Kinye mucii uyu \\ Giria ukinywe mbere: \\ Ni ntuuri ii}

\author{
Translation \\ Guard me: \\ As I enter this compound \\ Before: \\ This fool does so
}

Compound (mucii) in this particular stanza of the song refers to the newly created constituency of Chuka Igambang'ombe. In the stanza below, the composers are reffering to the same constituency as 'Mugunda wa Maguna' (Monkey's garden).

\section{Stanza}

Mugunda wa maguna:

Karabacha

liiiruri:

Karabacha

Chuka Igambang'ombe:

Karabacha

\section{Translation}

In the monkeys garden:

Karabacha

liiiruri:

Karabacha

Chuka Igambang'ombe:

Karabacha 
liiiruri:

Karabacha liiiruri:

Karabacha

The area referred to as the 'Monkey's Garden' is the Chuka Igambang'ombe constituency as it is indicated in the second stanza of this particular song. Reference to their constituency (Chuka Igambang'ombe) as their 'compound' and 'garden' demonstrated three things:

- That the Chuka people highly value their home place here referred to as the 'compound'.

- That since they are agriculturalists, they greatly value their gardens popularly referred to in Swahili as shamba.

- That they are one and should unite to elect political leaders who are prepared to spearhead development in their society.

Speaking about reference to place contexts, Senkoro (1987) asserts that such contexts gives the characters in a discourse an anchor. It shows where these characters hail from, where they are at present and probably where they purpose to go next. It gives them an identity. These characters have a unity of purpose as it is demonstrated in the stanza of the campaign song below:

\section{Stanza \\ Nitukumenya: \\ Buria tukwenda \\ Twiu nitwenda: \\ lii maendeleo}

\author{
Translation \\ Surely we know: \\ What we want \\ We want: \\ Development
}

Generally speaking, a critical analyst who is guided by C.D.A theory cannot fail to discuss the issue of context when dealing with a discourse. This is because one of the principles of this theory says that a full grasp of a message in a given discourse should focus on the context; be it real or fictional.

\subsection{Time Context}

After a close look at the place context in these Kichuka campaign songs, I shall now pay attention to its time context. The Kichuka campaign songs studied in this analysis can be placed in a certain time framework. However, the analyst takes cognizance of the fact that these particular songs may have been used earlier (in past general elections). The names of the politicians in these songs and the themes highlighted to a greater extent assist the analyst to correctly place them in a certain political epoch in the political history of the Chuka people. Some of these names are Njoka, Kapteni, Petkay, Kareke, Nthuraku Gichuiya, Kaburu, Muthomi Njuki, Mbabu, Mati, Njeru and Karagita. Most of the politician's names in these campaign songs are reffered to by only 'one' name. There are two reasons for this:

- When one declares interest for a certain political post, his/her interest spreads like wild fire in the electoral area concerned. Usage of one name does not pose problem to the electorate because these politicians are from their places and they know them. At times, they are even given nick names.

- To maintain the musical rhythm of the song. The syllabic beats that assist in maintaining the musical notes of the campaign songs are taken care of that way. Basically, the campaign songs are poetic in nature.

In December 1991, section 2(A) of the Kenyan Constitution was amended to create Kenya as a multiparty state. This new political scenario ignited a political excitement in Nithi Constituency. This was not peculiar to Nithi alone. Other parts of Kenya also experienced the same political excitement. Those who for a long time associated KANU (Kenya African National Union) - the then ruling party with repressiveness started expressing their innate disdain for this party through campaign songs in the national elections conducted in 1992.

Look at this:

\author{
Stanza 1 - 2 \\ Indi ninkinyu: \\ Nithi yonthe iii \\ Ya kubadilisha: \\ Nguku ninkwiu ii \\ lii wa Kathimbu: \\ Tutikumwenda ii \\ Indi ninkinyu: \\ Ya kubadilisha ii
}

\author{
Translation \\ Time has come: \\ For people in Nithi \\ To make a change: \\ The cock has died \\ This man with a stick: \\ We so not want him \\ Time has come: \\ To make a change
}


The 'cock' in this song symbolized the ruling party - KANU. The composers claim that 'the cock has died' symbolizing the political death of the then ruling party in Kenyan politics. The 'man with a stick' refers to the retired president Daniel Arap Moi. He was then the chairman of the then ruling party of KANU. The political climate in Nithi Constituency by then was against Moi and the ruling party of KANU. This partly explains existence of songs clamouring for a reason to elect a Mr. Njoka who was being sponsored by a rival political party D.P (The Democratic Party of Kenya) then chaired by the retired president Mwai Kibaki. Look at this:

\author{
Stanza \\ liiaiiiui: \\ Kiatho kiria gigukinya \\ liiaiiiui: \\ Kiatho kiria gigukinya \\ Twikie muti: \\ Kwa Njoka \\ Nake atigue: \\ Athakanagia na malaya iii
}

\author{
Translation \\ The long awaited day is here \\ The long awaited day is here \\ Let's vote: \\ Njoka in \\ Leave his opponents: \\ Continue flirting with prostitutes
}

It is in 2013 when Kenya Electoral and Boundaries Commission divided Nithi Constituency into the two new electoral areas of Chuka Igambang'ombe and Maara. Before this, rivalry between the Wachuka, Wamuthambi and Wamwimbi for political supremacy was evident in some of these Kichuka campaign songs. Each of these areas strove to produce one of their own as the area M.P. This explains why in the song 'Mbumbui' (The spider) the composers are calling upon the people from Chuka to make the spider bite Kareke (who hailed from Mwimbi) on the buttocks. A bite of the spider refers to refusal to vote for him. Look at this:

$\begin{array}{ll}\text { Stanza } & \text { Translation } \\ \text { Na Kareke: } & \text { Make Kareke: } \\ \text { Niarumithue mbumbui } & \text { To be bitten by the spider } \\ \text { Ya matina: } & \text { On the buttocks: } \\ \text { Agendage nayo } & \text { All the time }\end{array}$

In analyzing these Kichuka campaign songs, attention paid on time frame is as crucial as place context in that it sheds light on the reason for language usage and the message found in these campaign songs.

\subsection{Cultural Context}

The culture of a people refers to a total way of life of a people at a certain place in time. The C.D.A theory has it that interrogation of the cultural setting of a discourse assists to a greater degree in throwing light as to why certain words or group of words are used the way they are used in the discource in question. The composers of the Kichuka campaign songs demonstrate a deep understanding and appreciation of their cultural ingredients e.g.

\author{
Stanza \\ Kanyiri kainagua ni mwene: \\ Nitumuthureni \\ Uyu ni mwana wetu: \\ Nitumuthureni \\ Au nibo turi: \\ Nitumuthureni, \\ Kanyiri kainagua ni mwene
}

\author{
Translation \\ A people loves a Kinsman: \\ Let's elect him \\ This is our child: \\ Let's elect him \\ That's our decision: \\ Lets elect him \\ A people loves a Kinsmen
}

The composers of this particular campaign song are calling upon the Chuka electorate to elect 'one of their own' as the area M.P. He is their child hence a kinsman. It is the submission of this study that a person should be voted in a political office because of his ability to deliver in terms of development and not because of his 'blood proximity' with the voters. However, this particular song explains the attachment they have to a kinsman. According to the traditions of the Chuka people, betrayal of a kinsman is believed to attract a curse. Thoughts of this nature are witnessed in another campaign song called 'Utigakire' (Don't fear). Look at this:

Stanza 1 and 5 


\section{Stanza 1 \\ Ntari muci: \\ Ni mwana wetu \\ Watuma mbuca: \\ liiiui}

\section{Stanza 5 \\ Thii na mbere: \\ Utigakire \\ Mwana wetu: \\ liiiui}

\section{Translation}

I would not have come:

Were it not for our child

Who has made me to come:

liiiui

Here, the composers are exhorting 'their child' to forge ahead in the ongoing political competition for the seat of the M.P because he enjoys their full support. The main reason for supporting him is that he is their child. This kind of mindset in politics is retrogressive in that the electorate expects favours from one of their own. This partly explains why at times fights erupt based on clan affiliation in African politics.

There are some Kichuka campaign songs that testify as to their Christian religious faith (for most of the people). Some Christian songs are spiced with political undertones e.g.

$\begin{array}{ll}\begin{array}{l}\text { Stanza } \\ \text { Niwega Ngai: }\end{array} & \text { Translation } \\ \text { Mutongoria } & \text { Thanks to our Lord: } \\ \text { Nake Njuki: } & \text { Who guide us } \\ \text { Ni mumbunge } & \text { And Njuki: } \\ & \text { Is our M.P } \\ \text { Roho waku: } & \text { May your spirit: } \\ \text { Mutongorie } & \text { Guide him } \\ \text { Tutikabuute: } & \text { We will not go hungry: } \\ \text { Kana tunoonta } & \text { Or get thirsty }\end{array}$

This is a 'politicized Christian song' in Chuka community. This song presents as a prayer campaign song. The composers are calling upon God to guide a Mr. Njuki so that he can spearhead development in their locality. This clearly demonstrates that the Chuka people believe that prayers are able to shape the political landscape in their area.

The Chuka people of Kenya used to practice circumcision for their young boys and clitoridectomy for the young girls. During these ceremonies, circumcision songs were sang and highly valued. Due to western influence, the 'female cut' has stopped but male circumcision still continues but in hospitals. As I had pointed out, there was pomp and music during these ceremonies. During the electioneering period, some of these circumcision songs find their way in political arena but now in a revised form to accommodate the political message. For example:

\section{Stanza \\ Nthaka, nthaka, Nthaka: \\ Nthaka ni kithaka nthaka \\ Igendaga mbere ya riua: Nthaka \\ Igendaga na rukororima.}

\author{
Translation \\ Youngmen, youngmen, youngmen: \\ Youngmen are bushes \\ Wakes up before sunrise: \\ Youngmen \\ Wakes up very early.
}

The composers of this song lays claim that youngmen wakes up very early in the morning before the sun rises to go to vote for the candidate of their choice. This demonstrates the significance placed on the young energetic men in a political process in the Chuka community. They are the ones who can brave the cold of the night to campaign for the candidate they prefer or most of the times who has bought them beer or has given them handouts. Many a times they are misused by the aspiring politicians to cause mayhem against their opponents. Once bought beer or given handouts, they can sing praises for their paymaster the whole day and night braving the hassles of the weather.

The Chuka people are very careful in the way they use their language in their daily interactions. It's almost a taboo to mention private parts openly more especially in the presence of people who are not of your age. However, during the circumcision period, the society was 'on the loose' and some of these rules could be violated without raising eye brows. When these circumcision songs find their way in a campaigning exercise, this vulgar language is sometimes used. Look at this; 


\section{Stanza 1 - 2 \\ Giki ni kithii: \\ Karabacha \\ liiiruri: \\ Karabacha}

Gia kuthia mbene:

Karabacha

liiiruri:

Karabacha

\section{Translation}

This is a grinding machine:

Karabacha

liiiruri:

Karabacha

To grind the vagina:

Karabacha

liiiruri:

Karabacha

In the political context and more especially in a campaign rally, the political candidate whose candidate is being endorsed by the composers of this campaign song are referring to him as 'the grinding machine' that works on the vagina. This vulgar language is the political arena is an infiltration of such language from the community's circumcision songs.

\section{Conclusion}

In this study, I have first interrogated the language use in the campaign songs of the Chuka people in Tharaka Nithi County, Kenya. It is the submission of this study that the politicians and their supporters (composer of these songs) use language in these campaign songs with the sole aim of politically influencing the Chuka electorate for their own selfish end of getting political power. Usage of these Kichuka campaign songs is a power game in search of political influence. I have demonstrated that proper nouns, verbs and adjectives are used in a special way to achieve this political aim. Secondly, I have demonstrated that these Kichuka campaign songs attest to a certain place, time and cultural context. There are several indicators in these Kichuka campaign songs which show the locale of the Chuka people, a time or period in their history and the influences of their culture in these campaign songs. As I have stated earlier, a successful appreciation of a discourse should put into consideration the issue of context (contextualization of a discourse). Since these campaign songs appeal a lot to the emotions of a people, it's the humble submission of this study that to a greater degree these Kichuka campaign songs have influenced the voting patterns in their community with disastrous effects getting wrong political leaders who only serves their selfish ends leaving the common man wallowing in poverty and ignorance.

\section{References}

Birch, D. (1989). Language, Literature and Critical Approach. London: Routedge.

Guthrie, M. (1967). The Classification of the Bantu Languages. London: International African Institute.

Hirsch, E. D. (1967). Validity in Interpretation. New Haven \& London: Yale University Press.

Luke, A. (2005) Text and Discourse Analysis in Education. Creskill: Humpton Press.

Mathooko, P. M. (2007). Isimu Jamii: Misingi na Nadharia. Nairobi: Njigua Books.

Mesthrie, R. et al (2000). Introducing Socio-Linguistics. Edinburgh: Edinburgh Press.

Mgullu, R. (1999). Mtalaa wa Isimu: Fonetiki, Fonolojia na Mofolojia ya Kiswahili. Nairobi: Longhorn publishers.

Msanjila, Y. (1989) "Sociolinguistics - Rules of Formal Address in Kiswahili" Katika D.P.B Massamba (whr). Jarida la Taasisi ya Uchunguzi wa Kiswahili. Toleo 56 Dar es Salaam: TUKI pgs. 47 - 65.

Msokile, M. (1993). Misingi ya Uhakiki wa Fasihi. Nairobi: East African Educational Publishers.

Munene, S. (2011). "Uainishaji wa Mofimu za Kisarufi katika Kitenzi cha Kichuka". M. A. Thesis (unpublished). Chuka University.

Mwaniki, K. (1986). Categories and Substance of Embu Traditional Songs and Dances. Nairobi: Kenya Literature Bureau.

Mwaniki, K. (2004). Chuka Historical Texts. Nakuru: Media Document Supplies.

Senkoro, F. (1987). Fasihi na Jamii. Dar es Salaam: Press \& Publicity Centre.

Were, G. and Wilson, D. (1972). East Africa Through a Thousand Years. Nairobi: Evans Brothers Ltd. 